\title{
Agromyces luteolus sp. nov., Agromyces rhizospherae sp. nov. and Agromyces bracchium sp. nov., from the mangrove rhizosphere
}

Institute for Fermentation, Osaka, 17-85, Jusohonmachi 2-chome, Yodogawa-ku, Osaka 532-8686, Japan
Mariko Takeuchi and Kazunori Hatano

Author for correspondence: Mariko Takeuchi. Tel: +8106 6300 6555. Fax: +810663006814. e-mail: takeuchi-mariko@ifo.or.jp

\begin{abstract}
The taxonomic positions of four strains isolated from the mangrove rhizosphere were studied by a polyphasic approach using phenotypic, chemotaxonomic and genetic methods. The four isolates contain 2,4diaminobutyric acid in their peptidoglycan, and rhamnose as the major cell wall sugar. The predominant menaquinones are MK-12 and MK-11. The predominant cellular fatty acids are iso- $C_{16: 0}$, anteiso- $C_{15: 0}$ and/or anteiso- $C_{17: 0}$. The $\mathrm{G}+\mathrm{C}$ content of the DNA ranges from 70.0 to $73.3 \mathrm{~mol} \%$. The four strains formed a coherent cluster with Agromyces species in a phylogenetic inference based on 165 rDNA sequences. Interestingly, the four isolates grew well in the presence of $5 \% \mathrm{NaCl}$. The differences in some phenotypic and chemotaxonomic characteristics, 165 rDNA sequence similarity data and DNA-DNA relatedness data indicate that the four isolates represent three new species in the genus Agromyces, for which are proposed the names Agromyces luteolus for strain $8^{\top}$ (IFO $16235^{\top}=$ VKM AC-2085 $\left.{ }^{\top}\right)$, Agromyces bracchium for strain $65^{\top}$ (IFO $16238^{\top}=$ VKM AC-2088 ${ }^{\top}$ ) and Agromyces rhizospherae for strains $14^{\top}$ (IFO $16236^{\top}=$ VKM $^{\top}$ AC-2086') and 58(5) (IFO 16237 = VKM AC-2087).
\end{abstract}

Keywords: Agromyces luteolus sp. nov., Agromyces rhizospherae sp. nov., Agromyces bracchium sp. nov.

\section{INTRODUCTION}

The diversity and populations of micro-organisms in the mangrove rhizosphere have been studied at the Institute for Fermentation, Osaka (IFO) for several years. It has been suggested that the mangrove rhizosphere is a good source for isolating new and diverse actinomycetes (Hatano, 1997; Takeuchi \& Hatano, 1998, 1999). We have previously isolated 25 actinobacteria from the rhizosphere of mangroves in the estuary of the Shiira River, Iriomote Island, and determined their taxonomic positions at the genus level on the basis of phylogenetic and chemotaxonomic traits. Four strains were determined to be members of the genus Agromyces, 13 strains Cellulomonas, 2 strains Microbacterium, 2 strains Mycobacterium, 1 strain

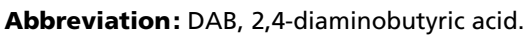

The DDBJ accession numbers for the 165 rDNA sequences determined in this study are AB023356-AB023359.
Micrococcus, 1 strain Gordonia and 1 strain Rhodococcus, and 1 strain which contained LL-diaminopimelic acid in the cell wall (Takeuchi \& Hatano, 1999) was of undetermined taxonomic position.

The object of the present study was to determine the exact taxonomic positions of the four strains of the genus Agromyces (Casida, 1986), strains 8 (IFO $16235^{\mathrm{T}}$ ), 14 (IFO $16236^{\mathrm{T}}$ ), 58(5) (IFO 16237) and 65 (IFO $16238^{\mathrm{T}}$ ), on the basis of morphological, physiological and chemotaxonomic characteristics, together with phylogenetic studies based on 16S rDNA sequences and DNA relatedness.

These strains are yellow, filamentous, elementary branching, irregular rod-shaped bacteria with all of the characteristic chemotaxonomic markers of the genus Agromyces, including 2,4-diaminobutyric acid (DAB) in their cell walls, DNA G $+\mathrm{C}$ contents ranging from 70.0 to $73.3 \mathrm{~mol} \%$, and MK-12 with smaller amounts of MK-11 and/or MK-13 menaquinones. 
The genus Agromyces was established by Gledhill \& Casida (1969) for the single species Agromyces ramosus, a filamentous, branching, catalase-negative actinomycete isolated from soil. Since then, two species each with two subspecies, Agromyces cerinus subsp. cerinus and Agromyces cerinus subsp. nitratus, and Agromyces fucosus subsp. fucosus and Agromyces fucosus subsp. hippuratus (Zgurskaya et al., 1992), and later a further species, Agromyces mediolanus (Suzuki et al., 1996), have been added to the genus.

By comparing the four isolates from the mangrove rhizosphere with previously described Agromyces species, we conclude that the four isolates represent three new species in the genus Agromyces. In this paper, we propose the new species names Agromyces luteolus for strain 8 (IFO $\left.16235^{\mathrm{T}}\right)$, Agromyces bracchium for strain 65 (IFO $16238^{\mathrm{T}}$ ) and Agromyces rhizospherae for strains 14 (IFO $16236^{\mathrm{T}}$ ) and 58(5) (IFO 16237).

\section{METHODS}

Bacterial strains and cultivation. Soil samples were taken from the rhizosphere of mangroves in the estuary of the Shiira River, Iriomote Island, Japan, in July 1997. Soils were stored at $5-8^{\circ} \mathrm{C}$, dried in air at $17^{\circ} \mathrm{C}$ for $6 \mathrm{~d}$, and then passed through sieves of 20 and 60 mesh to separate soil and fine roots. Strain 8 (IFO $16235^{\mathrm{T}}$ ) was isolated from the surface of roots of Sonneratia alba, strain 14 (IFO $16236^{\mathrm{T}}$ ) was isolated from soil of the rhizosphere of $S$. alba and strains 58(5) (IFO 16237) and 65 (IFO $16238^{\mathrm{T}}$ ) were isolated from soil of the rhizosphere of Bruguera gymnorrhiza by the method described by Hayakawa \& Nonomura $(1987,1989)$. A. cerinus subsp. cerinus IFO $15780^{\mathrm{T}}$, A. cerinus subsp. nitratus IFO $15783^{\mathrm{T}}$, A. fucosus subsp. fucosus IFO $15781^{\mathrm{T}}$, A. fucosus subsp. hippuratus IFO $15782^{\mathrm{T}}$ (Zgurskaya et al., 1992), A. mediolanus IFO $15704^{\mathrm{T}}$ (Suzuki et al., 1996) and $A$. ramosus IFO $13899^{\mathrm{T}}$ (Gledhill \& Casida, 1969) were used for comparison of physiological properties and for DNA-DNA hybridization tests with the isolates. Each strain was cultivated aerobically at $30{ }^{\circ} \mathrm{C}$ in peptone-yeast extract medium (PY medium) containing 1\% Polypepton (Wako Pure Chemicals), $0.2 \%$ yeast extract and $0.1 \% \quad \mathrm{MgSO}_{4} .7 \mathrm{H}_{2} \mathrm{O}$ $(\mathrm{pH} 7 \cdot 2)$. Cells used for biochemical tests were harvested by centrifugation during the stationary phase, washed with water and lyophilized.

Morphological and physiological characterization. For investigation of morphological characteristics, cultures grown on PY medium to the early growth phase (approx. $16 \mathrm{~h}$ ) and to stationary phase at $30^{\circ} \mathrm{C}$ were observed with a light microscope and a scanning electron microscope (model JSM-5400; JEOL). Samples for scanning electron microscopy were prepared by fixing in $2 \%$ glutaraldehyde in potassium phosphate buffer for $4 \mathrm{~h}$ at $4{ }^{\circ} \mathrm{C}$ and $1 \%$ osmic acid in potassium phosphate buffer for $16 \mathrm{~h}$ at $4{ }^{\circ} \mathrm{C}$, dehydrating through a graded acetone series, critical point drying (model HCP-2; Hitachi Koki), and then sputtercoating with palladium under vacuum. Motility was determined by the hanging-drop method. Biochemical characteristics of the Agromyces strains were examined by using the API CORYNE system and API 50CH with AUX Medium. Other physiological characteristics were determined as described by Cowan \& Steel (1965).
Chemotaxonomic characterization. Analyses of cell wall amino acid and sugar composition and the acyl type of the peptidoglycan, menaquinone composition, cellular fatty acid composition and DNA G $+\mathrm{C}$ content were performed as described previously (Takeuchi \& Hatano, 1998).

DNA-DNA hybridization. DNA-DNA hybridization was carried out fluorometrically in microdilution wells by using biotinylated DNA (Ezaki et al., 1989).

16S rDNA sequence determination and phylogenetic analysis. A 16 S rDNA fragment corresponding to position 8-1540 in the Escherichia coli numbering system (Brosius et al., 1978) was amplified by PCR, sequenced directly with a ThermoSequenase cycle sequencing kit with 7-deaza-dGTP (Amersham), and analysed with a LI-COR 4200L-2 (2-dye system) DNA sequencer, following the manufacturer's instructions. The $16 \mathrm{~S}$ rDNA sequences were aligned with published sequences available from DDBJ, EMBL and GenBank. 'Agromyces succinolyticus' is a DAB-containing coryneform bacterium isolated from soil (K.-I. Suzuki \& J. Sasaki, unpublished data). The Clustal w version 1.6 (Thompson et al., 1994) software package was used to generate the evolutionary distances ( $K_{\text {nuc }}$ values) (Kimura, 1980) and the similarity values. A phylogenetic tree was constructed by the neighbour-joining method (Saitou \& Nei, 1987), and the topology of the tree was evaluated by the bootstrap resampling method (Felsenstein, 1985) with 1000 replicates.

\section{RESULTS AND DISCUSSION}

\section{Morphological and physiological characteristics}

The four strains studied in this work were Grampositive, non-spore-forming, irregular rods. The cells measured $0 \cdot 2-0 \cdot 4$ by $1 \cdot 5-6.0 \mu \mathrm{m}$ long (Fig. 1a); they differed in length from strain to strain, and tended to be shorter in old cultures as shown in Fig. 1(b). Filamentous elongation and branching were observed in strains IFO $16235^{\mathrm{T}}$, IFO $16236^{\mathrm{T}}$ and IFO $16238^{\mathrm{T}}$, but were not observed obviously in strain IFO 16237. All strains formed yellow to pale yellow, entire, convex colonies on PY medium agar. Colonies sometimes penetrated into the agar. Aerial mycelia were not produced.

All strains grew optimally at a temperature of 20 $30^{\circ} \mathrm{C}$, but did not grow at 10 or $37^{\circ} \mathrm{C}$. They grew well in the presence of $5 \% \mathrm{NaCl}$, but very little in the presence of $8 \% \mathrm{NaCl}$. All strains were positive for catalase, hydrolysis of aesculin, gelatin and starch (data not shown). Using the API CORYNE system, pyrazinamidase and aesculinase were positive, but alkaliphosphatase, nitrate reductase, $\beta$-glucuronidase, $\beta$-galactosidase, $\alpha$-glucosidase and $N$-acetyl $\beta$ glucosaminidase were negative for all strains. Using the API $50 \mathrm{CH}$ system, acid was produced from fructose, glucose, maltose and mannose, but was not produced from adonitol, D-arabinose, L-arabitol, dulcitol, erythritol, D-fucose, $N$-acetylglucosamine, $\alpha$-methyl-D-glucoside, glycerol, inositol, inulin, $\alpha$ methyl-D-mannoside, sorbitol, sorbose, D-tagatose, L-xylose, $\beta$-methyl-D-xyloside or xylitol. Other biochemical characteristics that showed different results 
(a)

(i)

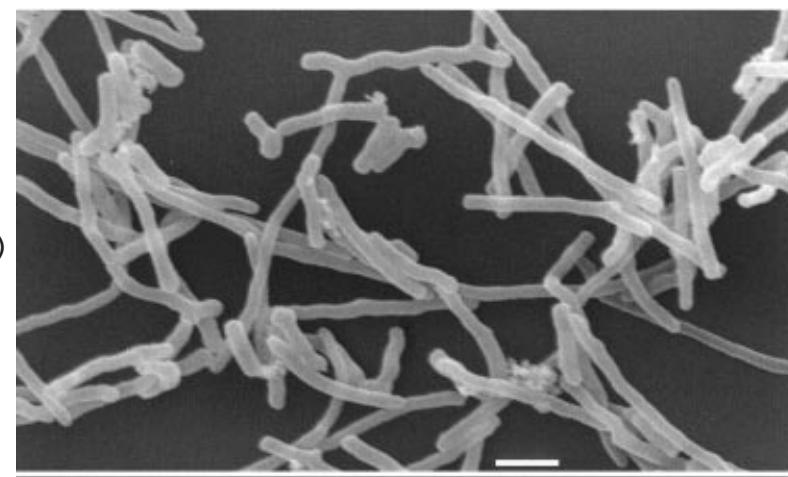

(ii)

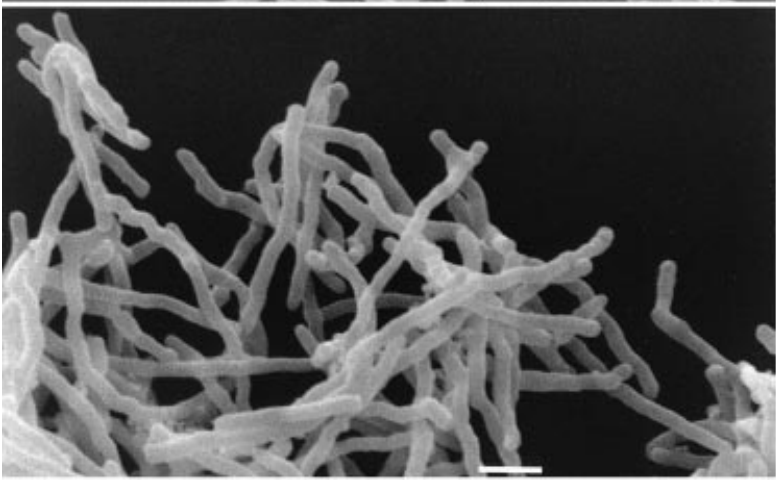

(iii)
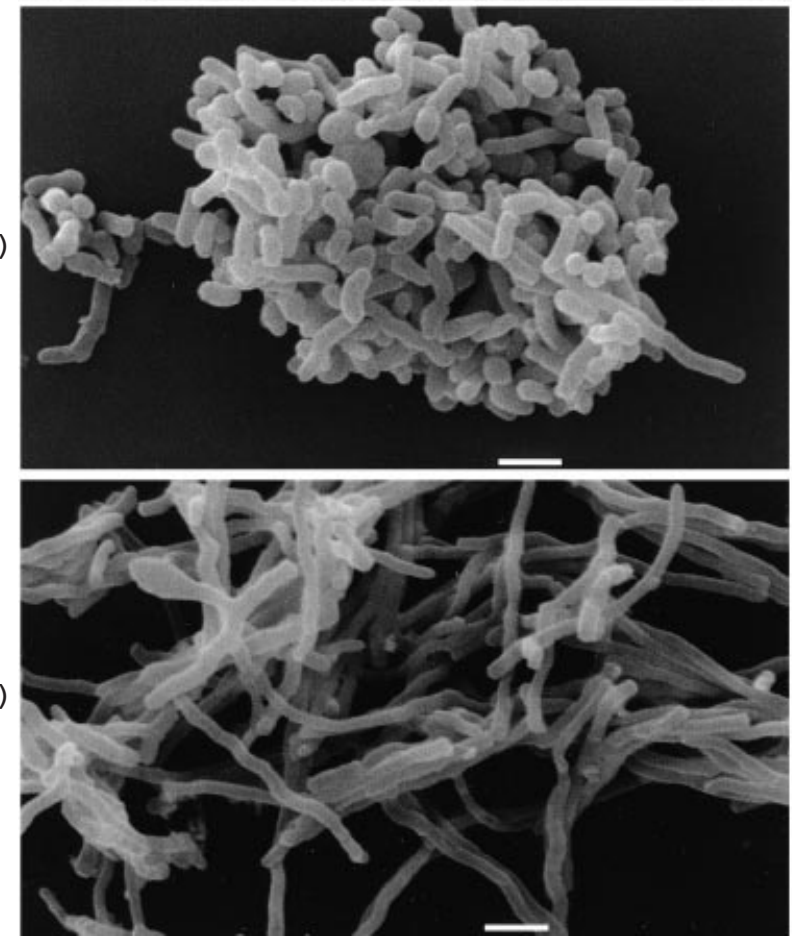

(b)
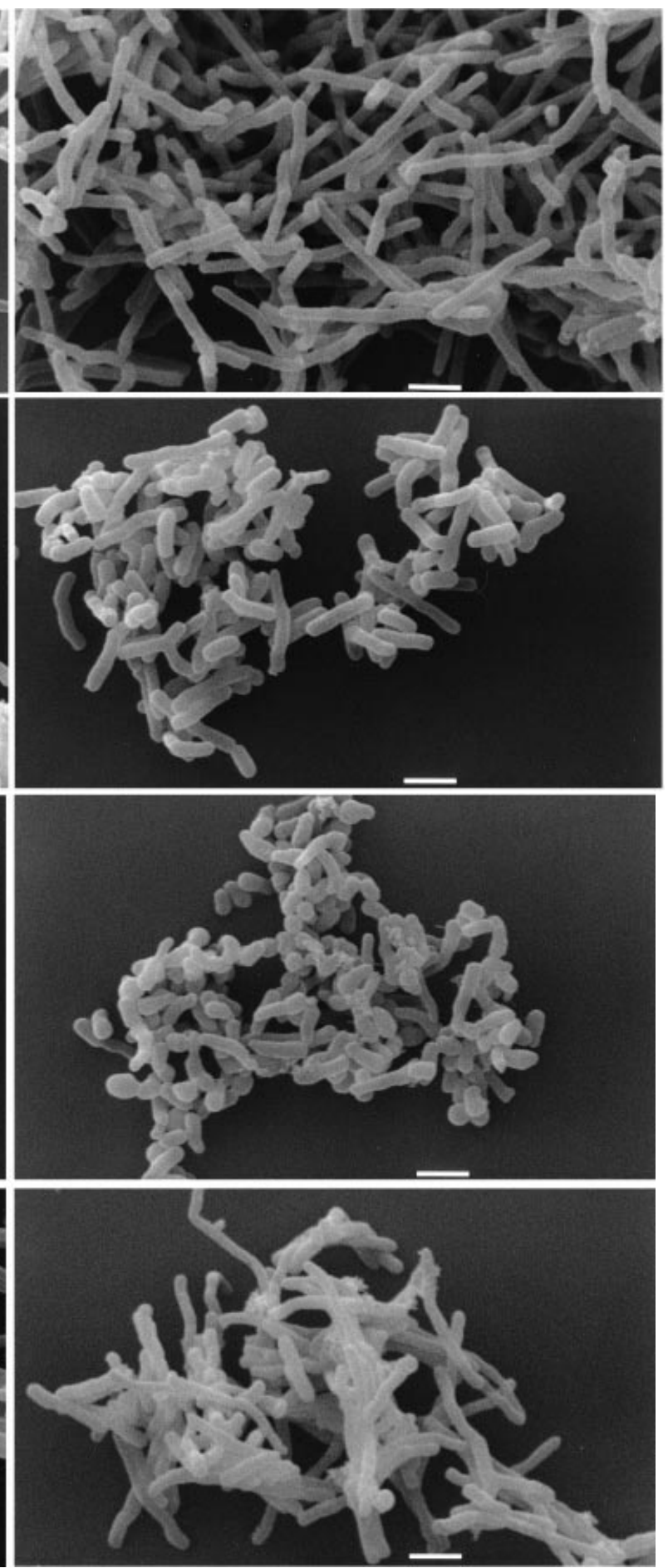

Fig. 1. Scanning electron micrographs of $A$. luteolus, $A$. rhizospherae and $A$. bracchium grown on $\mathrm{PY}$ medium at $30^{\circ} \mathrm{C}$. $A$. luteolus IFO $16235^{\top}$ (i), A. rhizospherae IFO $16236^{\top}$ (ii), $A$. rhizospherae IFO 16237 (iii) and $A$. bracchium IFO $16238^{\top}$ (iv) in the early growth phase (a) and in the exponential growth phase (b). Bars, $1 \mu \mathrm{m}$.

among the four strains are shown in Table 1. Two strains, IFO $16236^{\mathrm{T}}$ and IFO 16237, showed the same results in the API 50CH system with regard to acid production from all carbohydrates except for glycogen and lactose. Strain IFO $16235^{\mathrm{T}}$ was differentiated from strains IFO $16236^{\mathrm{T}}$ and IFO 16237 by acid production from amidon, cellobiose, gentibiose, salicin and trehalose. Strain IFO $16238^{\mathrm{T}}$ was differentiated from IFO 
Table 1. Biochemical characteristics that differentiate the four new Agromyces strains

+ , Positive reaction; $+\mathrm{w}$, weakly positive reaction; - , negative reaction.

\begin{tabular}{|c|c|c|c|c|}
\hline \multirow[t]{2}{*}{ Characteristic } & \multirow{2}{*}{$\begin{array}{l}\text { A. luteolus } \\
\text { IFO } 16235^{\mathrm{T}}\end{array}$} & \multicolumn{2}{|c|}{ A. rhizospherae } & \multirow{2}{*}{$\begin{array}{l}\text { A. bracchium } \\
\text { IFO } 16238^{T}\end{array}$} \\
\hline & & IFO $16236^{T}$ & IFO 16237 & \\
\hline Pyrrolidonyl arylamidase* & + & + & + & - \\
\hline \multicolumn{5}{|l|}{ Acid production from: $\dagger$} \\
\hline Amidon & - & + & + & + \\
\hline Amygdalin & - & - & - & + \\
\hline L-Arabinose & - & - & - & + \\
\hline Arbutin & - & - & - & + \\
\hline Cellobiose & - & + & + & + \\
\hline Galactose & - & - & - & + \\
\hline Gentiobiose & - & $+\mathrm{w}$ & $+\mathrm{w}$ & + \\
\hline Gluconate & - & - & - & + \\
\hline Glycogen & - & + & - & + \\
\hline Lactose & + & - & + & + \\
\hline Mannitol & $+\mathrm{w}$ & - & - & + \\
\hline Melezitose & - & - & - & $+\mathrm{w}$ \\
\hline Melibiose & $+\mathrm{w}$ & - & - & + \\
\hline Raffinose & - & - & - & + \\
\hline Rhamnose & $+w$ & - & - & $+\mathrm{w}$ \\
\hline Ribose & - & - & - & + \\
\hline Salicin & - & + & $+\mathrm{w}$ & + \\
\hline Sucrose & $+\mathrm{w}$ & - & - & + \\
\hline Trehalose & + & - & - & + \\
\hline D-Turanose & - & - & - & + \\
\hline D-Xylose & - & - & - & + \\
\hline
\end{tabular}

* API CORYNE system.

$\dagger$ Carbohydrate assimilation reactions: API 50CH and AUX medium, incubated at $30{ }^{\circ} \mathrm{C}$.

$16235^{\mathrm{T}}$, IFO $16236^{\mathrm{T}}$ and IFO 16237 by pyrrolidonyl arylamidase activity and by acid production from amygdalin, L-arabinose, arbutin, galactose, gluconate, melezitose, raffinose, ribose, D-turanose and D-xylose.

\section{Chemotaxonomic characteristics}

The molar ratio of glycine, alanine and $\mathrm{DAB}$ to glutamic acid in the cell wall peptidoglycan isolated from cells of strains IFO $16235^{\mathrm{T}}$, IFO $16236^{\mathrm{T}}$, IFO 16237 and IFO $16238^{\mathrm{T}}$ was $(0 \cdot 85-1 \cdot 31):(0 \cdot 55-$ $0 \cdot 62):(1 \cdot 38-1 \cdot 77): 1 \cdot 00$, as shown in Table 2 . This ratio is the same as that obtained for A. ramosus ATCC $25173^{\mathrm{T}}(0 \cdot 98: 0 \cdot 71: 1 \cdot 73: 1 \cdot 00)$ (Fiedler \& Kandler, 1973). These cell walls were of an acetyl type. The main sugar component of the cell wall of all strains was rhamnose, and small amounts of glucose and mannose were also detected in the cell walls of all the strains studied. In addition, fructose and galactose were present in the cell walls of strains IFO $16235^{\mathrm{T}}$ and IFO $16238^{\mathrm{T}}$, respectively.

All the four strains had cellular fatty acids of the isoand anteiso-branched type. All except IFO $16238^{\mathrm{T}}$ contained iso- $\mathrm{C}_{16: 0}$ as the primary cellular fatty acid and anteiso- $\mathrm{C}_{15: 0}$ as the second most common type. IFO $16238^{\mathrm{T}}$ contained anteiso- $\mathrm{C}_{15: 0}$ as the primary cellular fatty acid and iso- $\mathrm{C}_{16: 0}$ and anteiso- $\mathrm{C}_{17: 0}$ as the second most common types. All strains except for IFO $16238^{\mathrm{T}}$ contained MK-12 and MK-11 as the major menaquinones. IFO $16238^{\mathrm{T}}$ contained MK-12 as the major menaquinone and MK-13 as the second most common type.

\section{Phylogenetic analysis}

The 16S rDNA sequences of the four strains IFO $16235^{\mathrm{T}}$, IFO $16236^{\mathrm{T}}$, IFO 16237 and IFO $16238^{\mathrm{T}}$ were compared with representative members of the genus Agromyces and related micro-organisms. A phylogenetic tree (Fig. 2) showed that they formed a coherent cluster with species of the genus Agromyces (Takeuchi \& Hatano, 1999). Strains IFO $16236^{\mathrm{T}}$ and IFO 16237 had a $16 \mathrm{~S}$ rDNA sequence similarity value of $99 \cdot 2 \%$ with each other, and they represented a distinct lineage within the genus Agromyces with similarity values of $96.5-97.8 \%$ among the representative strains of previously described Agromyces species (data not shown). Strains IFO $16235^{\mathrm{T}}$ and IFO 
Table 2. Chemotaxonomic characteristics of the four new Agromyces strains

\begin{tabular}{|c|c|c|c|c|}
\hline \multirow[t]{2}{*}{ Characteristic } & \multirow{2}{*}{$\begin{array}{l}\text { A. luteolus } \\
\text { IFO } 16235^{\mathrm{T}}\end{array}$} & \multicolumn{2}{|c|}{ A. rhizospherae } & \multirow{2}{*}{$\begin{array}{l}\text { A. bracchium } \\
\text { IFO } 16238^{\mathrm{T}}\end{array}$} \\
\hline & & IFO $16236^{\mathrm{T}}$ & IFO 16237 & \\
\hline \multicolumn{5}{|c|}{$\begin{array}{l}\text { Amino acid composition of cell wall } \\
\text { (molar ratio to glutamic acid) }\end{array}$} \\
\hline Glutamic acid & $1 \cdot 00$ & $1 \cdot 00$ & $1 \cdot 00$ & $1 \cdot 00$ \\
\hline Glycine & $1 \cdot 15$ & $0 \cdot 85$ & $1 \cdot 25$ & $1 \cdot 31$ \\
\hline Alanine & $0 \cdot 55$ & $0 \cdot 60$ & $0 \cdot 56$ & $0 \cdot 62$ \\
\hline $\mathrm{DAB}$ & $1 \cdot 77$ & $1 \cdot 38$ & $1 \cdot 56$ & $1 \cdot 47$ \\
\hline \multicolumn{5}{|c|}{ Sugar composition of cell wall $(\%)$} \\
\hline Galactose & - & - & - & 6 \\
\hline Glucose & 2 & 5 & 4 & 7 \\
\hline Fructose & 25 & - & - & - \\
\hline Mannose & 6 & 6 & 7 & 7 \\
\hline Rhamnose & 67 & 89 & 89 & 80 \\
\hline \multicolumn{5}{|c|}{ Cellular fatty acid composition ( $\%)$} \\
\hline iso- $\mathrm{C}_{14: 0}$ & $4 \cdot 1$ & - & $1 \cdot 0$ & - \\
\hline iso- $\mathrm{C}_{15: 0}$ & $6 \cdot 1$ & $7 \cdot 7$ & $9 \cdot 3$ & $4 \cdot 3$ \\
\hline iso- $\mathrm{Cl}_{6: 0}$ & $47 \cdot 9$ & $53 \cdot 3$ & $43 \cdot 9$ & $28 \cdot 1$ \\
\hline anteiso- $\mathrm{C}_{15: 0}$ & $32 \cdot 5$ & $26 \cdot 1$ & $27 \cdot 0$ & $41 \cdot 6$ \\
\hline anteiso- $\mathrm{C}_{17: 0}$ & $9 \cdot 4$ & $12 \cdot 9$ & $18 \cdot 9$ & $26 \cdot 0$ \\
\hline \multicolumn{5}{|c|}{ Major menaquinone (\%) } \\
\hline MK-11 & 35 & 48 & 19 & 8 \\
\hline MK-12 & 65 & 52 & 81 & 78 \\
\hline MK-13 & - & - & - & 14 \\
\hline
\end{tabular}

$16238^{\mathrm{T}}$ had a $16 \mathrm{~S}$ rDNA sequence similarity value of $98.4 \%$ with each other. The closest species to these two strains was $A$. mediolanus, but the levels of $16 \mathrm{~S}$ rDNA sequence similarity between these strains and $A$. mediolanus was 97.5 and $97.7 \%$, respectively (data not shown).

\section{DNA base composition and DNA-DNA hybridization}

The DNA base composition of the four strains ranged from 70.0 to $73.3 \mathrm{~mol} \%$, as shown in Table 3. The levels of DNA-DNA relatedness between IFO $16236^{\mathrm{T}}$ and IFO 16237 were 69 and $73 \%$, but levels of DNA-DNA relatedness among these two strains and other strains studied in the genus Agromyces were $11-22 \%$. These results show that the two strains should be considered as a new species in the genus Agromyces. In addition, strains IFO $16235^{\mathrm{T}}$ and IFO $16238^{\mathrm{T}}$ also showed levels of DNA-DNA relatedness of 13 and $36 \%$ with each other, and 8 to $36 \%$, and 13 to $39 \%$, respectively, with other strains studied. These results show that strains IFO $16235^{\mathrm{T}}$ and IFO $16238^{\mathrm{T}}$ also each represent a new species in the genus Agromyces.

The high values of $16 \mathrm{~S}$ rDNA sequence similarity and DNA-DNA relatedness between strains IFO $16236^{\mathrm{T}}$ and IFO 16237, and the low levels of DNA-DNA relatedness among these strains and previously described species in the genus Agromyces, confirmed that the two strains IFO $16236^{\mathrm{T}}$ and IFO 16237 represent a new species in the genus Agromyces. Similarly, the low levels of DNA-DNA relatedness between strains IFO $16235^{\mathrm{T}}$ and IFO 15238, and among these strains and other strains used in this study confirmed that strains IFO $16235^{\mathrm{T}}$ and IFO $16238^{\mathrm{T}}$ each represents a new species in the genus Agromyces. From the above results, we propose three new species in the genus Agromyces, Agromyces rhizospherae for strains IFO $16236^{\mathrm{T}}$ and IFO 16237, A. luteolus for strain IFO $16235^{\mathrm{T}}$ and $A$. bracchium for strain IFO $16238^{\mathrm{T}}$.

The phenotypic characteristics also distinguish these three new species from the previously described species and subspecies in the genus Agromyces, as shown in Table 4. A. mediolanus is the closest species to $A$. bracchium and A. luteolus on the basis of phylogenetic analysis (Fig. 2), but they can be differentiated by nitrate reduction, urease production, hydrolysis of starch and acid production from glycerol, fructose, rhamnose and mannitol. The finding that all strains of the new species studied grew well in the presence of $4 \%$ $\mathrm{NaCl}$, in contrast to almost all Agromyces species described previously, is very interesting from the viewpoint of ecology, because the soils of the mangrove rhizosphere have higher salinity than terrestrial soils (Wakushima et al., 1994).

The sugar components of the cell walls are also useful to distinguish the three new species from the previously described Agromyces species, as shown in Table 4. All strains of the new species studied contained rhamnose 


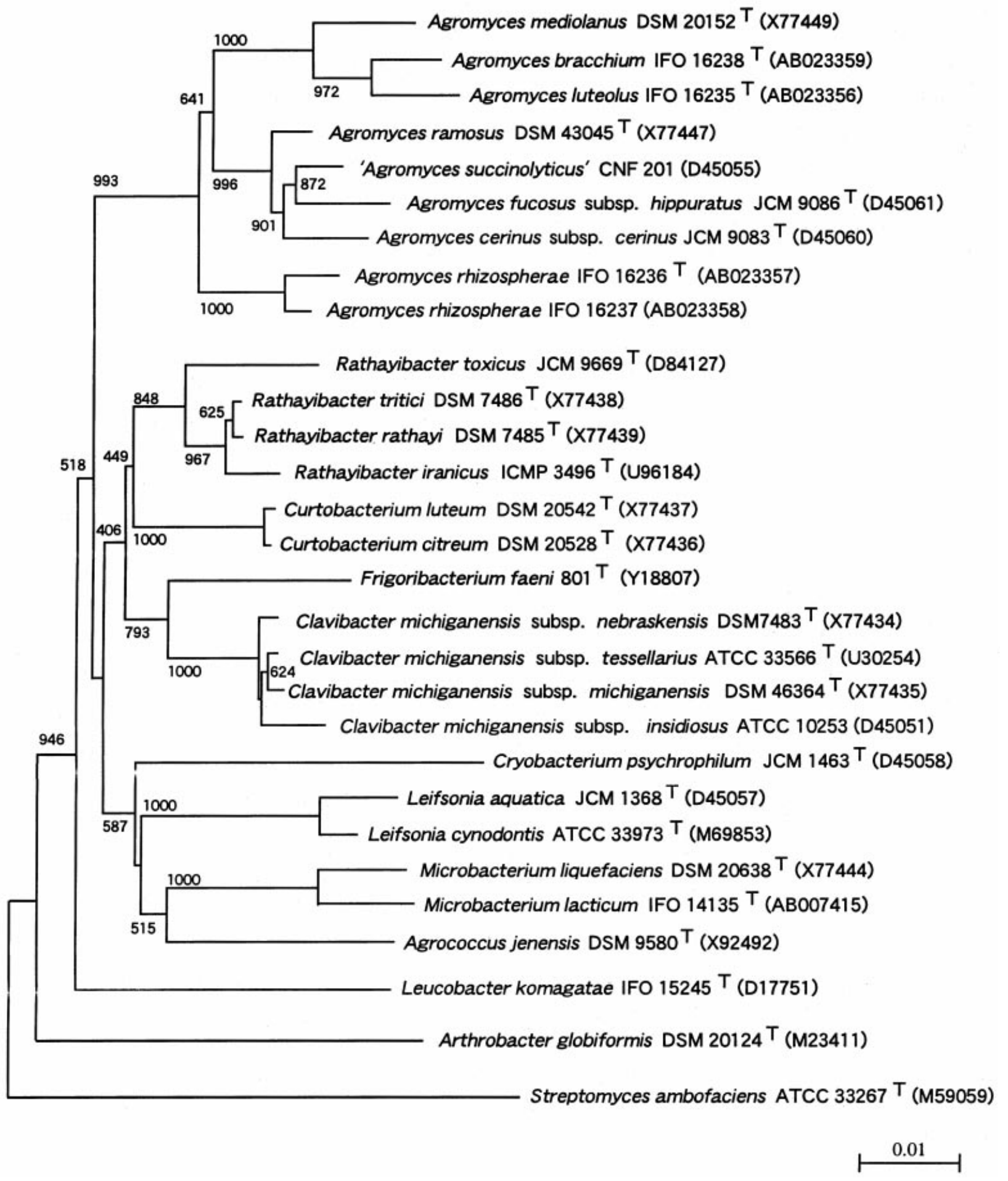

Fig. 2. Unrooted phylogenetic tree showning the relationship of $A$. luteolus, $A$. rhizospherae and $A$. bracchium to related micro-organisms. The numbers indicate the percentages of bootstrap samplings, derived from 1000 samplings of the internal branches (Felsenstein, 1985).

as the major cell wall sugar; galactose was not found as a major component. A. luteolus was also characterized by having fructose in the cell wall. In contrast, all the previously described species or subspecies in the genus
Agromyces contain galactose as the major cell wall sugar. A. ramosus also contains xylose (Gledhill \& Casida, 1969), and A. cerinus subsp. cerinus also contains tyvelose in their cell walls, and $A$. cerinus 
Table 3. DNA base compositions and levels of DNA-DNA homology of Agromyces species

\begin{tabular}{|c|c|c|c|c|c|}
\hline \multirow[t]{2}{*}{ Species } & \multirow{2}{*}{$\begin{array}{c}\mathbf{G}+\mathbf{C} \text { content } \\
(\mathrm{mol} \%)\end{array}$} & \multicolumn{4}{|c|}{$\%$ DNA-DNA reassociation with: } \\
\hline & & IFO $16235^{\mathrm{T}}$ & IFO $16236^{\mathrm{T}}$ & IFO 16237 & IFO $16238^{\mathrm{T}}$ \\
\hline A. luteolus IFO $16235^{\mathrm{T}}$ & $71 \cdot 1$ & 100 & 27 & 27 & 13 \\
\hline A. rhizospherae IFO $16236^{\mathrm{T}}$ & $71 \cdot 2$ & 13 & 100 & 69 & 31 \\
\hline A. rhizospherae IFO 16237 & $73 \cdot 3$ & 8 & 73 & 100 & 39 \\
\hline A. bracchium $\mathrm{IFO} 16238^{\mathrm{T}}$ & $70 \cdot 0$ & 36 & 13 & 14 & 100 \\
\hline A. mediolanus IFO $15704^{\mathrm{T}}$ & $72 \cdot 3$ & 21 & 11 & 18 & 24 \\
\hline A. ramosus IFO $13899^{\mathrm{T}}$ & 68.9 & 15 & 19 & 13 & 18 \\
\hline A. cerinus subsp. cerinus IFO $15780^{\mathrm{T}}$ & $70 \cdot 5$ & 24 & 20 & 18 & 13 \\
\hline A. cerinus subsp. nitratus IFO $15783^{\mathrm{T}}$ & $70 \cdot 9$ & 28 & 15 & 17 & 26 \\
\hline A. fucosus subsp. fucosus IFO $15781^{\mathrm{T}}$ & $70 \cdot 6$ & 10 & 18 & 13 & 31 \\
\hline A. fucosus subsp. hippuratus IFO $15782^{\mathrm{T}}$ & $70 \cdot 8$ & 31 & 14 & 22 & 24 \\
\hline
\end{tabular}

Table 4. Characteristics that differentiate the species and subspecies of the genus Agromyces

1, A. luteolus; 2, A. rhizospherae; 3, A. bracchium; 4, A. mediolanus; 5, A. ramosus; 6, A. cerinus subsp. cerinus; 7, A. cerinus subsp. nitratus; 8, A. fucosus subsp. fucosus; 9, A. fucosus subsp. hippuratus. Data for all species except $A$. luteolus, $A$. rhizospherae and A. bracchium are from Gledhill \& Casida (1969), Zguraskaya et al. (1992) and Suzuki et al. (1996). +, 90\% or more of strains positive;,$- 90 \%$ or more of strains negative; $+\mathrm{w}$, weakly positive reaction; $\mathrm{v}$, variable reaction; ND, not determined.

\begin{tabular}{|c|c|c|c|c|c|c|c|c|c|}
\hline Characteristic & 1 & 2 & 3 & 4 & 5 & 6 & 7 & 8 & 9 \\
\hline Catalase production & + & + & + & + & - & + & + & + & + \\
\hline Nitrate reduction & - & - & - & + & - & - & + & - & + \\
\hline Urease production & - & - & - & + & $\mathrm{V}$ & - & - & - & - \\
\hline Starch hydrolysis & + & + & + & - & + & + & + & + & + \\
\hline \multicolumn{10}{|l|}{ Acid production from: } \\
\hline Glycerol & - & - & - & + & + & + & - & - & + \\
\hline Ribose & - & - & + & + & + & - & - & - & - \\
\hline Galactose & - & - & + & + & $\mathrm{V}$ & + & - & - & - \\
\hline Glucose & + & + & + & + & + & - & - & - & - \\
\hline Fructose & + & + & + & - & $\mathrm{V}$ & + & - & - & - \\
\hline Mannose & + & + & + & + & $\mathrm{V}$ & - & - & - & - \\
\hline Rhamnose & $+\mathrm{w}$ & - & $+\mathrm{w}$ & - & + & + & + & - & + \\
\hline Mannitol & $+\mathrm{w}$ & - & + & - & + & - & - & - & - \\
\hline Amygdalin & - & - & + & - & ND & + & - & - & - \\
\hline Aesculin & + & + & + & + & $\mathrm{V}$ & + & + & + & - \\
\hline Salicin & - & + & + & $+\mathrm{w}$ & $\mathrm{V}$ & + & - & - & - \\
\hline Maltose & + & + & + & + & + & + & - & - & - \\
\hline Sucrose & $+\mathrm{w}$ & - & + & + & + & - & - & - & - \\
\hline Growth in $4 \% \mathrm{NaCl}$ & + & + & + & ND & $\mathrm{V}$ & - & - & - & $\mathrm{V}$ \\
\hline Growth at $37^{\circ} \mathrm{C}$ & - & - & - & ND & $\mathrm{V}$ & - & + & - & - \\
\hline Cell wall sugars* & $\begin{array}{l}\text { Rha, Fruc, } \\
\text { (Glc, Man) }\end{array}$ & $\begin{array}{l}\text { Rha, (Glc, } \\
\text { Man) }\end{array}$ & $\begin{array}{l}\text { Rha, (Gal, } \\
\text { Glc, Man) }\end{array}$ & ND & $\begin{array}{c}\text { Gal, Glc, Man, } \\
\text { Rha, Xyl }\end{array}$ & $\begin{array}{l}\text { Gal, Rha, } \\
\text { Tyv, (Man) }\end{array}$ & $\begin{array}{l}\text { Gal, (Glc, } \\
\text { Man) }\end{array}$ & $\begin{array}{l}\text { Gal, Rha, } \\
\text { (Glc, Man) }\end{array}$ & $\begin{array}{l}\text { Gal, Rha, } \\
\text { (Man) }\end{array}$ \\
\hline
\end{tabular}

* Rha, rhamnose; Fruc, fructose; Glc, glucose; Man, mannose; Xyl, xylose; Tyv, tyvelose. Parentheses indicate that a compound may or may not be present.

subsp. nitratus is characterized by the absence of rhamnose.

On the basis of the phenotypic, chemotaxonomic and phylogenetic studies, as well as DNA-DNA relatedness data, we conclude that the four isolates represent three new species in the genus Agromyces.

\section{Description of Agromyces luteolus sp. nov.}

Agromyces luteolus (lu.te'o.lus. N.L. adj. luteus yellow; M.L. dim. adj. luteolus yellowish, somewhat yellow).

Cells are aerobic, Gram-positive, irregular rods that form filaments $(0 \cdot 2-0 \cdot 4$ by $3 \cdot 0-5 \cdot 0 \mu \mathrm{m})$ or show el- 
ementary branching in the early growth phase and fragment into short rods $(0 \cdot 2-0.4$ by $2 \cdot 0-3.0 \mu \mathrm{m})$ during exponential growth phase. Colonies on PY agar medium are yellow to whitish yellow, opaque, entire and convex, and sometimes penetrate into the agar. Grows optimally at $20-30{ }^{\circ} \mathrm{C}$, but does not grow at 10 or $37^{\circ} \mathrm{C}$. Catalase-positive. Acid is produced from glucose, fructose, lactose, maltose, mannose and trehalose, but is not produced from adonitol, amidon, amygdalin, arabinose, arbutin, cellobiose, dulcitol, erythritol, fucose, galactose, gentiobiose, gluconate, glycerol, glycogen, inositol, inulin, melezitose, raffinose, ribose, salicin, sorbitol, sorbose, tagatose, turanose, xylose or xylitol. Aesculin, gelatin and starch are hydrolysed. Urease is not produced. DAB is the principal amino acid of the cell wall peptidoglycan. The cell wall is of an acetyl type. The predominant isoprenoid quinone is MK-12, with small amounts of MK-11. The predominant cellular fatty acids are iso$\mathrm{C}_{16: 0}$ and anteiso- $\mathrm{C}_{15: 0}$. The $\mathrm{G}+\mathrm{C}$ content of the DNA is $71.1 \mathrm{~mol} \%$. Isolated from soil of rhizosphere of mangrove on Iriomote Island, Japan. The type strain is IFO $16235^{\mathrm{T}}\left(=\right.$ VKM Ac- $\left.2085^{\mathrm{T}}\right)$.

\section{Description of Agromyces rhizospherae sp. nov.}

Agromyces rhizospherae (rhi.zo'spher.ae. M.L. rhizo root; Gr. adj. sphera sphere; M.L. n. rhizospherae within the sphere of the root).

Cells are aerobic, Gram-positive, irregular rods that form filaments $(0 \cdot 2-0.4$ by $1.5-3.0 \mu \mathrm{m})$ or show elementary branching in the early growth phase and fragment into short rods $(0.2-0.4$ by $0.8-1.5 \mu \mathrm{m})$ during exponential growth phase. Colonies on PY agar medium are yellow, opaque, entire and convex, and sometimes penetrate into the agar. Grows optimally at $20-30{ }^{\circ} \mathrm{C}$, but does not grow at 10 or $37^{\circ} \mathrm{C}$. Catalasepositive. Acid is produced from amidon, cellobiose, fructose, gentiobiose, glucose, maltose, mannose, salicin, but is not produced from adonitol, amygdalin, arabinose, arabitol, arbutin, cellobiose, dulcitol, erythritol, fucose, galactose, gluconate, glycerol, inositol, mannitol, melezitose, raffinose, rhamnose, ribose, sorbitol, sorbose, sucrose, tagatose, trehalose, turanose, xylose or xylitol. Aesculin, gelatin and starch are hydrolysed. Urease is not produced. DAB is the principal amino acid of the cell wall peptidoglycan. The cell wall is of an acetyl type. The predominant isoprenoid quinones are MK-12 and MK-11. The predominant cellular fatty acids are iso- $\mathrm{C}_{16: 0}$ and anteiso- $\mathrm{C}_{15: 0}$. The $\mathrm{G}+\mathrm{C}$ content of the DNA is $71 \cdot 2-73 \cdot 3 \mathrm{~mol} \%$. Isolated from soil of or roots in rhizosphere of mangrove on Iriomote Island, Japan. The type strain is IFO $16236^{\mathrm{T}}$ (=VKM Ac- $\left.2086^{\mathrm{T}}\right)$. The other strain is IFO 16237 (= VKM Ac-2087).

\section{Description of Agromyces bracchium sp. nov.}

Agromyces bracchium (bracchi.um. M.L. adj. bracchium like a twig).
Cells are aerobic, Gram-positive, irregular rods that form filaments $(0 \cdot 2-0 \cdot 4$ by $5 \cdot 0-6 \cdot 0 \mu \mathrm{m})$ or show elementary branching in the early growth phase and fragment into short rods $(0 \cdot 2-0 \cdot 4$ by $1 \cdot 5-3 \cdot 0 \mu \mathrm{m})$ during exponential growth phase. Colonies on PY agar medium are yellow, opaque, entire and convex, and sometimes penetrate into the agar. Grows optimally at $20-30{ }^{\circ} \mathrm{C}$, but does not grow at 10 or $37^{\circ} \mathrm{C}$. Catalasepositive. Acid is produced from amidon, amygdalin, L-arabinose, arbutin, cellobiose, fructose, galactose, gentiobiose, gluconate, glucose, glycogen, lactose, maltose, mannitol, mannose, melezitose, melibiose, raffinose, rhamnose, ribose, salicin, sucrose, trehalose, D-turanose and D-xylose, but is not produced from adonitol, D-arabinose, arabitol, dulcitol, erythritol, fucose, glycerol, inositol, inulin, sorbitol, sorbose, tagatose, L-xylose or xylitol. Aesculin, gelatin and starch are hydrolysed. Urease is not produced. DAB is the principal amino acid of the cell wall peptidoglycan. The cell wall is of an acetyl type. The predominant isoprenoid quinone is MK-12 with small amounts of MK-13 and MK-11. The predominant cellular fatty acids are anteiso- $\mathrm{C}_{15: 0}$, anteiso- $\mathrm{C}_{17: 0}$ and iso- $\mathrm{C}_{16: 0}$. The $\mathrm{G}+\mathrm{C}$ content of the DNA is $70.0 \mathrm{~mol} \%$. Isolated from soil of rhizosphere of mangrove on Iriomote Island, Japan. The type strain is IFO $16238^{\mathrm{T}}(=\mathrm{VKM}$ Ac- $2088^{\mathrm{T}}$ ).

\section{ACKNOWLEDGEMENTS}

We thank Dr Ludmila Evtushenko, VKM-All-Russian Collection of Microorganisms, Skryabin Institute of Biochemistry and Physiology of Microorganisms, Russian Academy of Sciences, for valuable suggestions and discussion. We thank Kozaburo Mikata, Senior Research Head of yeast in the Institute for Fermentation, Osaka, for his help with scanning electron microscopy. We also thank Yayoi Yamaguchi for her excellent technical assistance.

\section{REFERENCES}

Brosius, J., Palmer, J. L., Kennedy, J. P. \& Noller, H. F. (1978). Complete nucleotide sequence of a $16 \mathrm{~S}$ ribosomal RNA gene from Escherichia coli. Proc Natl Acad Sci U S A 76, 4801-4805.

Casida, L. E. (1986). Genus Agromyces Gledhill and Casida 1969c, 346 ${ }^{\mathrm{AL}}$. In Bergey's Mannual of Systematic Bacteriology, vol. 2, pp. 1329-1331. Edited by P. H. A. Sneath, N. S. Mair, M. E. Sharpe \& J. G. Holt. Baltimore: Williams \& Wilkins.

Cowan, S. T. \& Steel, K. J. (1965). Manual for the Identification of Medical Bacteria. London: Cambridge University Press.

Ezaki, T., Hashimoto, Y. \& Yabuuchi, E. (1989). Fluorometric deoxyribonucleic-deoxyribonucleic acid hybridization in microdilution wells as an alternative to membrane filter hybridization in which radioisotopes are used to determine genetic relatedness among bacterial strains. Int J Syst Bacteriol 39, 224-229.

Felsenstein, J. (1985). Confidence limits on phylogenies: an approach using the bootstrap. Evolution 39, 783-791.

Fiedler, F. \& Kandler, O. (1973). Die Aminosäuresequenz von 2,4diamino- buttersäure enthaltender mureinen bei verschiedenen coryneformen bakterien und Agromyces ramosus. Arch Mikrobiol 89, 51-66.

Gledhill, W. E. \& Casida, L. E., Jr (1969). Predominant catalase- 
negative soil bacteria. III. Agromyces, gen. nov., microorganisms intermediary to Actinomyces and Nocardia. Appl Microbiol 18, 340-349.

Hatano, K. (1997). Actinomycete populations in mangrove rhizospheres. IFO Res Commun 18, 26-31.

Hayakawa, M. \& Nonomura, H. (1987). Efficacy of artificial humic acid as a selective nutrient in HV agar used for the isolation of soil actinomycetes. J Ferment Technol 65, 609-616.

Hayakawa, M. \& Nonomura, H. (1989). A new method for the intensive isolation of actinomycetes from soil. Actinomycetologica 3, 95-104.

Kimura, M. (1980). A simple method for estimating evolutionary rates of base substitutions through comparative studies of nucleotide sequences. J Mol Evol 16, 111-120.

Saitou, N. \& Nei, M. (1987). The neighbor-joining method: a new method for reconstructing phylogenetic trees. Mol Biol Evol 4, 406-425.

Suzuki, K.-I., Sasaki, J., Uramoto, M., Nakase, T. \& Komagata, K. (1996). Agromyces rediolanus sp. nov., nom. rev., comb. nov., a species for "Corynebacterium mediolanum" Mamoli 1939 and for some aniline-assimilating bacteria which contain 2,4diaminobutyric acid in the cell wall peptidoglycan. Int $J$ Syst Bacteriol 46, 88-93.
Takeuchi, M. \& Hatano, K. (1998). Gordonia rhizosphera sp. nov. isolated from the mangrove rhizosphere. Int J Syst Bacteriol 48, 907-912.

Takeuchi, M. \& Hatano, K. (1999). Phylogenetic analysis of actinobacteria in the mangrove rhizosphere. IFO Res Commun 19, 47-62.

Thompson, J. D., Higgins, D. G. \& Gilson, T. J. (1994). CLUSTAL W: improving the sensitivity of progressive multiple sequence alignment through sequence weighting, position-specific gap penalties and weight matrix choice. Nucleic Acids Res 22, 4673-4680.

Wakushima, S., Kuraishi, S. \& Sakurai, N. (1994). Soil salinity and $\mathrm{pH}$ in Japanese mangrove forests and growth of cultivated mangrove plants in different soil conditions. J Plant Res 107, 39-46.

Zgurskaya, H. I., Evtushenkio, L. I., Akimov, V. N., Voyevoda, H. V., Dobrovolskaya, T. G., Lysak, L. V. \& Kalakoutskii, L. V. (1992). Emended description of the genus Agromyces and description of Agromyces cerinus subsp. cerinus sp. nov., subsp. nov., Agromyces cerinus subsp. nitratus sp. nov., subsp. nov., Agromyces fucosus subsp. fucosus sp. nov., subsp. nov., and Agromyces fucosus subsp. hippuratus sp. nov., subsp. nov. Int $J$ Syst Bacteriol 42, 635-641. 